\title{
FEDERAL DEFENDER SERVICES: SERVING THE SYSTEM OR THE CLIENT?
}

\author{
JOHN J. CLEARY*
}

INTRODUCTION

Thirty years ago, Congress enacted the Criminal Justice Act of 1964, thus ensuring that those charged with federal crimes who are financially unable to employ counsel ${ }^{1}$ would receive effective assistance of counsel. ${ }^{2}$ During the first year of operation under that Act, the federal courts made 16,000 compensated appointments of counsel. ${ }^{3}$ Today that number has risen to approximately $89,000{ }^{4}$

The annual appropriation for compensation of attorneys and necessary defense expenses has grown from \$1 million in 1965 to more than \$300 million today. ${ }^{5}$ With this explosion of financial support has come judicial control over defense counsel. This judicial domination denies defender services their

Copyright $\odot 1995$ by Law and Contemporary Problems
$*$ Partner, Cleary \& Sevilla, San Diego; Executive Director, Federal Defenders of San Diego, Inc. (1971-83); Deputy Director, National Defender Project of the National Legal Aid and Defender Association (1964-69).

1. Three out of every four defendants charged with a serious crime are unable to afford counsel. Statistics are not maintained on the percentage of federal defendants represented by appointed counsel. The $75 \%$ estimate is based upon observations of federal appointments and data on the percentage of defendants with appointed counsel in state cases, where the standard of indigence may be more stringent than the federal test of "financially unable to obtain adequate representation." 18 U.S.C. $\$$ $3006 \mathrm{~A}$ (a). A recent study of state cases in three major cities (Detroit, Seattle, and Denver) found an average $84 \%$ of all felony defendants had appointed counsel. NATIONAL CTR. FOR STATE COURTS, INDIGENT DEFENDERS: GET THE JOB DONE AND DONE WELL 13 (1992). This important statistic should be compiled for federal courts.

2. Criminal Justice Act of 1964, Pub. L. No. 88-455, \& 2, 78 Stat. 552 (1964) (codified as amended at 18 U.S.C. \& 3006A (1988)).

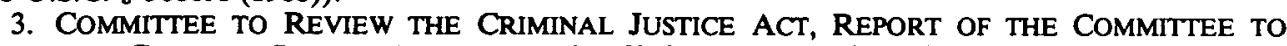
REVIEW THE CRIMINAL JUSTICE ACT, reprinted in 52 Crim. L. Rep. (BNA) 2265, 2269 (Mar. 10, 1993) [hereinafter COMMTTEE REPORT].

4. Id. at 2279. One measure of the growth of federal criminal litigation is the number of major criminal offenses. In fiscal year 1964, there were more than 29,000 filings (charges, which may have more than one defendant), of which almost 5,000 involved auto theft in interstate commerce. ADMINISTRATIVE OFFICE OF THE U.S. COURTS., 1964 ANNUAL REPORT OF THE DIRECTOR OF THE ADMINISTRATIVE OFFICE OF THE U.S. COURTS 254. In 1993, there were approximately 65,000 major criminal defendants, of which only 547 involved auto theft. ADMINISTRATIVE OFFICE OF THE U.S. COURTS, JUDICIAL BUSINESS OF THE UNTTED STATES COURTS: REPORT OF THE DIRECTOR, in 1993 UNITED STATES COURTS: SELECTED REPORTS 124, 320. Appointments of counsel exceed these figures because counsel is also appointed in misdemeanor cases, and appointments are made at different stages of a criminal proceeding: e.g., revocation of probation or supervised release, appeal, post-conviction petition, and others.

5. COMMITTEE REPORT, supra note 3, at 2269. 
independence and thereby fulfills a 1963 prophecy that such defender services would become so institutionalized that they would serve the system rather than the client. ${ }^{6}$

The manner in which defender services are rendered in federal criminal trials has assumed ever-increasing importance. In the past, federal courts with limited jurisdiction had few criminal cases; the states have long been primarily responsible for the enforcement of criminal laws. Since the 1930s, however, federal criminal jurisdiction has expanded. For example, since 1971, the federal courts have had jurisdiction over any drug offense, even simple possession. ${ }^{7}$ In response to the intense public concern with crime fanned by unprincipled politicians, federal criminal jurisdiction has continually grown to include crimes originally handled by the states. This has led to concurrent jurisdictions with combined and overlapping enforcement agencies. On September 13, 1994, President Clinton signed the Violent Crime Control and Law Enforcement Act of $1994,{ }^{8}$ which is more political posturing on crime, emphasizing punishment without addressing the causes and conditions of crime. The political manipulation of crime issues prevents objective assessment of crime control measures and protection of the rights of an accused. Part II of this article provides an overview of the development of the Sixth Amendment right to counsel, including the creation of federal defender offices. Part III argues for independence at the national level-in structure and funding-for the federal public defender service organizations, and Part IV argues for additional independence at the local level. Part V briefly sets out other necessary reforms in the federal defender program, including term limits and training for federal defenders, continuity of representation on appeal, and affording the clients a limited right to select counsel.

II

\section{HISTORY OF THE RIGHT TO COUNSEL AND FEDERAL DEFENDER OFFICES}

The Sixth Amendment right to counsel in the trial of a criminal case, adopted in 1791, actually broke with English precedent that disfavored the intervention of counsel as a disruptive force in the criminal process. ${ }^{9}$ The new sixth amendment protection recognized that counsel is essential for the accused engaged in vital combat against the powerful and skilled legal representatives and almost limitless resources of the state. In the early years of the protection,

6. See discussion infra notes $14-15$ and accompanying text.

7. Controlled Substances Act, Pub. L. No. 91-513, tit. II, 85 Stat. 1242 (1970) (codified as amended at 21 U.S.C. $\S \S 801-904$ (1988 \& Supp. V 1994)).

8. Pub. L. No. 103-322, 108 Stat. 1796 (1994).

9. It was an ancient principle of English common law that no person accused of treason or a felony against the Crown was permitted counsel. An accused was first allowed counsel in cases of treason in 1696 and in cases of felony in 1837. THEODORE F. T. PLUCKNETT, A CONCISE HISTORY OF THE COMMON LAW 434-35 (5th ed. 1956). 
the right to counsel was more a myth than a reality for those without funds. In 1932, however, the United States Supreme Court held that the Due Process Clause of the Fourteenth Amendment requires a defendant in a capital murder case to have a qualified lawyer capable of early investigation, adequate preparation, and continuous consultation. ${ }^{10}$ Six years later, the right to effective assistance of counsel was formally extended to federal felony cases. ${ }^{11}$ However, not until twenty-five years later-in 1963-did the right become applicable to the states through the Due Process Clause of the Fourteenth Amendment. ${ }^{12}$

Prior to 1965, in federal criminal cases, the right to counsel for those financially unable to retain counsel was the general responsibility of the bar, and the courts would often appoint unwilling or inexperienced lawyers without compensation for services or necessary expenses. While allocating no funds for defense, the annual federal budget for federal criminal investigative agencies exceeded the total cost of operation of the federal judiciary. To rectify the imbalance, Congress enacted the Criminal Justice Act of 1964 (the "CJA"), which for the first time provided minimal compensation for appointed lawyers and reimbursement for the expenses of experts and others.

For many years prior to the adoption of the CJA U.S. Attorneys General had repeatedly recommended some system of compensated defense service. These recommendations culminated in Attorney General Robert Kennedy ordering the first comprehensive review of federal defender services, the 1963 Allen Report. ${ }^{14}$ The Allen Report recommended payment for appointed counsel and the creation of public defender offices, but only the former recommendation was initially adopted by Congress. The Allen Report also repeated the reservations about creating a federal public defender under the influence and control of the judiciary, and it attempted to attenuate this control by placing the power of appointment in the judicial council of the circuit. ${ }^{15}$ Concerns had been expressed that full-time defender offices would become institutionalized, and the interests of the defender staff attorney would become aligned and identified more with the bureaucracy than with the impoverished and unpopular client.

In 1964, the Ford Foundation awarded a $\$ 6.1$ million grant to the National Legal Aid and Defender Association for the founding of the National Defender Project to create and support organized defender offices. The National

10. Powell v. Alabama, 287 U.S. 45 (1932).

11. Johnson v. Zerbst, 304 U.S. 458 (1938).

12. Gideon v. Wainwright, 372 U.S. 335 (1963).

13. Criminal Justice Act $\S 2,78$ Stat. at 552 .

14. Professor Francis A. Allen, chairman, filed the REPORT OF THE ATTORNEY GENERAL's COMMISSION ON POVERTY AND THE ADMINISTRATION OF FEDERAL CRIMINAL JUSTICE [hereinafter ALLEN REPORT] on February 25, 1963, a few weeks before the decision in Gideon (decided on March 18). In 1971, when Congress created full-time federal defender offices, it followed the format set forth in the Allen Report.

15. Id. at 41 . 
Defender Project, under the leadership of General Charles L. Decker, subsidized prototype federal defender offices in Chicago, San Francisco, San Diego, and Phoenix. These were either branches of a legal aid society (San Francisco and Phoenix) or separate nonprofit corporations (Chicago and San Diego). Each federal office had a small full-time staff to represent clients, but the nucleus staff also assisted panel attorneys and employed law students. In 1970, when Congress considered amendments to the CJA, these prototype federal defender offices served as the models for the full-time federal defender offices.

Effective in 1971, Congress for the first time authorized two alternative types of full-time defender offices, the federal public defender organization (the "FPDO") and the community defender organization (the "CDO"). ${ }^{16}$ To create a defender organization, a district must have at least $200 \mathrm{CJA}$ appointments per year. ${ }^{17}$ To preserve local preference, the qualified district court determines which organization would better suit local needs. Approval of the plan, however, rests with the judicial council of the federal circuit, a governing council consisting of district and appellate judges. To provide oversight at a national level, Congress placed the administration and financing of federal defender services under the Judicial Conference of the United States and the Administrative Office of the U.S. Courts in Washington. ${ }^{18}$ The Judicial Conference establishes policy through its Committee on Defender Services. It administers programs through the Administrative Office of the U.S. Courts. The Administrative Office operates through its Defender Services Division, which processes the budgets for both FPDOs and CDOs, but the courts approve the individual vouchers of appointed attorneys and experts.

Today, a total of seventy-one of the ninety-four federal districts have a fulltime federal defender organization. There are forty-eight FPDOs operating in fifty-eight districts and eleven CDOs in thirteen districts. In addition, there are twenty specialized CDOs, entitled Death Penalty Resource Centers, which represent petitioners in federal capital habeas corpus proceedings. At the trial and appellate level, if an eligible defendant is not represented by a defender organization, the court appoints individual counsel from local panels. Thus, in addition to serving defendants in the twenty-three districts that have no federal defender organization, panel attorneys represent eligible defendants that the FPDO or the CDO cannot represent due to workload or conflicts. Today, the

16. Act of Oct. 14, 1970, Pub. L. No. $91-447,84$ Stat. 916.

17. 18 U.S.C. $\$ 3006 \mathrm{~A}(\mathrm{~g})(1)$. Both the Committee Report and the Report of the Judicial Conference recommended abolishing the 200-case requirement and creating a defender office wherever economically feasible. COMMITTEE REPORT, supra note 3, at 2294; JUDICIAL CONFERENCE OF THE U.S., REPORT OF THE JUDICIAL CONFERENCE OF THE UNITED STATES ON THE FEDERAL DEFENDER PROGRAM 21 (1993) [hereinafter CONFERENCE REPORT]. The COMMITTEE REPORT also recommended creating a full- or part-time resource or support person for appointed counsel in those districts without a defender office. COMMITTEE REPORT, supra note 3, at 2303.

18. The Judicial Conference of the United States oversees the delivery of federal defender services and establishes national guidelines under its rulemaking power. 18 U.S.C. $\S 3006 \mathrm{~A}(\mathrm{~h})$. 
representation of approximately 89,000 eligible clients is split almost equally between the full-time staff of defender organizations and individually appointed counsel. ${ }^{19}$

\section{III}

\section{INDEPENDENCE AT THE NATIONAL LEVEL}

In January 1993, the Report of the Committee to Review the Criminal Justice Act, ${ }^{20}$ commonly referred to as the Prado Committee Report after its chairman-Judge Edward C. Prado of the U. S. District Court for the Western District of Texas, ${ }^{21}$ recommended a substantial restructuring of federal defender services to ensure their independence by placing the national administration of defense services in a separate Center for Federal Criminal Defense Services ("Federal Center"). The work now done by the Judicial Conference of the United States and the Administrative Office of the U. S. Courts would then be done by a separate entity, but still within the judicial branch. $^{22}$

The Prado Committee had relied on the historical need to separate the functions in the adversary system and the American Bar Association standards that expressly prohibit judicial control over defender services. The judge, who can directly or indirectly appoint the defender or control the compensation of the panel attorney or expert, controls the defense of the case. This proposed shift away from the pervasive control now exercised by the judiciary over all aspects of the delivery of defender services met with resistance, not only from the judiciary, but from a majority of federal public defenders, who had been appointed by judges. Those who prefer the status quo find no faults worth such major restructuring and believe that the system for defense of the often unpopular indigent can be better funded as an integral part of the judiciary rather than as a separate entity.

19. Of the approximately 89,000 persons represented under the CJA during fiscal year 1993 , the Prado Committee estimated that approximately 47,000 (53\%) would be represented by the defender organizations and $42,000(47 \%)$ by appointed counsel. COMMITEE REPORT, supra note 3, at 2279.

20. The Judicial Improvements Act of 1990, Pub. L. No. 101-650, tit. III, § 318, 104 Stat. 5089, 5116, directed the Judicial Conference to conduct a study on the effectiveness of federal defender services. This congressional action was a response to the report of the Federal Courts Study Committee, which recommended a comprehensive review of the CJA and compensation for appointed counsel: "Congress should amend 18 U.S.C. $\S 3006 \mathrm{~A}(\mathrm{~g})(2)(\mathrm{A})$ to require that the selection of the federal defender in each jurisdiction be done by an independent board or commission formed within the district to be served." JUDICIAL CONFERENCE OF THE U.S., REPORT OF THE FEDERAL COURTS STUDY COMMITTEE 157 (1990).

21. The committee's membership included two federal judges, two federal defenders (one federal public defender and one executive director of a community defender organization), general counsel of a state public defender office, two private practitioners, and two law professors (one a former judge). COMMITTEE REPORT, supra note 3, at 2268-69.

22. Id. at 2299. Four members of the committee, three defenders and a criminal defense attorney, filed a separate report, protesting the placement in the judiciary, because independence would not be achieved if judges had "control over the appointment of the administrators of the defense delivery system." Id. at 2307-08. 
In March 1993, this controversial centerpiece proposal of the Prado Committee was rejected by the Judicial Conference, which recommended that supervision and direction of federal defender services remain with the Judicial Conference and the Administrative Office. ${ }^{23}$ The Judicial Conference substituted its own report for that of the Prado Committee and submitted that to Congress. The Judicial Conference also rejected the recommendation of a separate budget for federal defender services. ${ }^{24}$ However, the Judicial Conference's report to Congress makes many positive recommendations for reform, from better panel attorney compensation to the development of attorney performance standards. These are needed changes, but the underlying theme of the report is defender "business as usual" under the control of the judiciary.

Not all the judges agreed with the conclusion of the Judicial Conference. ${ }^{25}$ Circuit Judge Stephanie K. Seymour, a former Chair of the Committee on Defender Services, urged a change in the administrative structure:

Although it may have been wise to place the defender services program under the guidance of the judiciary in the program's infancy, logically the defense component of our criminal justice system should be as independent of the decision maker as is the prosecution. It is uncomfortable and a bit unseemly for the very judges before whom the criminal defense lawyer must try his or her cases to participate in the selection of that lawyer or to decide his or her compensation. ${ }^{26}$

Under the rejected Prado Committee proposal, the Chief Justice would have appointed the governing board of the new Federal Center. This board would consist of seven members with experience in federal criminal defense, but neither prosecutors nor, ultimately, judges. ${ }^{27}$ The four dissenters on the Prado Committee would have had the Chief Justice make the appointments from a list composed of recommendations from a variety of bar and other organizations with experience in federal criminal defense. ${ }^{28}$

Neither the Prado Committee majority nor the dissenters went far enough, because they left the Federal Center within the judiciary. The federal defenders must be recognized as an independent structure if they are to have true parity,

23. The Judicial Conference found that the Prado Committee's recommendation for an independent national center was based on a "perceived" need supported only by "anecdotal statements of a lack of independence and the potential of occasional abuse." CONFERENCE REPORT, supra note 17, at 16. As further support for rejecting the proposal, the Judicial Conference also found that the defenders themselves were opposed to creating a new national apparatus, such an apparatus would be more costly in time of financial restraint, and defender programs would lose judicial support. Id. at 17.

24. Id. at 13 .

25. It is ironic that the judiciary, which obtained its administrative independence from the Department of Justice more than 50 years ago through the creation of its own separate national administration, the Administrative Office of the U.S. Courts, would begrudge the defenders their independence. Act of Aug. 7, 1939, ch. 501, $\$ 1,53$ Stat. 1223 (codified as amended at 28 U.S.C. $\$ \$ 601-612$ (1988 \& Supp. V 1994)) (creating the Administrative Office).

26. COMMITTEE REPORT, supra note 3, at 2287.

27. Id. at 2299. The proposal allowed for as many as two of the initial members to be federal judges. Any judge who was an initial member could be reappointed to a second three-year term. With that exception, no active or senior federal judge would be eligible.

28. Id. at 2308 . 
both with their adversary, the federal prosecutors, and with the courts before which they practice.

Congress has already provided an independent mechanism for the delivery of civil legal assistance for those unable to afford it through the creation in 1974 of the Legal Services Corporation (the "LSC"). ${ }^{29}$ The proposed independent Federal Center should be created as the Defender Services Corporation to finance, support, and establish policy regarding these legal services in criminal cases. It should not be a part of the judiciary and ought to receive the same neutral treatment as do civil legal services, which, unlike legal representation in criminal cases, are not mandated by the Sixth Amendment. As suggested by the Prado Committee dissenters, the members of the Federal Center might be appointed by the Chief Justice, but from lists furnished by designated legal service organizations. The Defender Services Corporation would perform the role now performed by the Judicial Conference and the Administrative Office and no more. Neither the Federal Center nor its officers should develop into a "Defender Czar." Instead, the Federal Center should have national independent standing to balance the political power of the Department of Justice in the administration of the federal criminal laws.

Those who criticize the LSC are not familiar with its history. After 1964, this financing of civil legal services was operated as a part of the Office of Economic Opportunity. However, the grantees of legal services needed financial independence from the administration, whose acts they were regularly challenging in court. Finally, shortly before his resignation in 1974, President Nixon signed this legislation, which may have been an unsuccessful attempt to appease Congress with legislation he would not have otherwise supported. Although the Reagan Administration sought to abolish the LSC by withholding funding, its attack initiated a response by Congress to continue and expand funding for these legal services, even though they were not constitutionally mandated. Now the House of Representatives, in its zeal to curtail unnecessary spending, has again targeted civil legal services for the poor. ${ }^{30}$ This easy budget-cutting target has survived so far only because the legal community has strongly supported the poor's access to the civil courts.

The LSC has provided national funding of civil legal services for twenty years and has not impaired the necessary autonomy of the local legal services programs. The LSC does not appoint the local directors of the programs. However, it does ensure that federal funds are properly and efficiently spent,

29. Legal Services Corporation Act of 1974, Pub. L. No. 93-355, § 2, 88 Stat. 378 (codified as amended at 42 U.S.C.S. $\$ \$ 2996 a-29961$ (1988 \& Supp. V 1994)). Congress created this D.C. private, nonmembership, nonprofit corporation with a board of directors of 11 voting members appointed by the President with the advice and consent of the Senate. No more than six voting members could be of the same political party, and the board included representatives of the general bar, legal services attorneys, and the general public. 42 U.S.C. $\$ \S 2996$ b(a), 2996c (1988).

30. One House Budget Committee proposal would be a five-year phase-out of the LSC, which has been allocated \$415 million for fiscal year 1995. Claudia MacLachlan, Legal Services Comes Under Attack-Again, NAT'L. L.J., Apr. 3, 1995, at A12. 
by means of an audit system much more extensive than that now available to review how CJA funds are spent. The LSC has achieved the dual goal of combining national funding and oversight with local control. The grantees of the LSC are usually legal aid societies or similar organizations that have representatives from the bar and the community to preserve their independence. In the LSC, Congress has a successful working model for fashioning an independent agency for federal defender services. Congress should not allow deliberate judicial self-interest, as expressed by the Judicial Conference's rejection of the Prado Committee's recommendation, to prevent it from following the LSC model and giving defenders independence from the judiciary.

Some of the public defenders who opposed the Prado Committee recommendation have suggested that they must remain in the judiciary to preserve their funding. However, the judiciary, as the weakest branch of Government, has a difficult time securing funding for its own programs, and if its funds ever need to be restricted, the federal defender step-child will be the last to be considered and the first to be cut. The defenders need their own voice in Congress, not a judicial echo unable to point out the present disparity between gargantuan funding for the prosecution and inadequate funding for federal criminal defense. ${ }^{31}$ When Congress creates new federal crimes, expands federal criminal jurisdiction, or passes unfair minimum mandatory sentences, it should be forced by an agency with expertise in the area to consider the impact on federal defender services. Such expertise is not now available from a minuscule part of the large judicial apparatus, which properly shirks the role of advocacy in opposition to proposed legislation.

The annual appropriation for the Defense Services Corporation, which would fund defense representation exclusively in federal criminal trials, should be considered in conjunction with the budgets of the Department of Justice and the judiciary. Fundamental fairness transcends political parties, and Congress would see the corresponding need to provide the minimum funds for defense when it considered the massive and disproportionate expenses for the prosecution and federal investigative agencies. Senators and congressional representatives take an oath to support the Constitution (including the Sixth Amendment right to counsel), and it would be presumptuous to assume that they would begrudge less to constitutionally required services than they allocate now for non-mandated civil legal services.

Because of the opposition of the Judicial Conference and a majority of federal public defenders, the Prado Committee's meritorious recommendation of a separate organization for the delivery of defender services has little chance of legislative success. At a minimum, however, Congress should direct that the

31. During the last two fiscal years, the initial CJA appropriation has been exhausted, and the Administrative Office has had to temporarily curtail payment of vouchers for legal and other services. The last-minute supplemental appropriations demonstrate that the judiciary, as the inappropriate advocate for defense funding, has not been successful even in meeting the existing, limited requests for financing. 
existing Defender Services Committee, which is the real policy body for defender services, include at least defense counsel representatives. ${ }^{32}$ Several critics have complained for years that this committee is not really equipped to evaluate the critical defender issues without active voting participation of federal criminal defense practitioners. ${ }^{33}$ The Prado Committee's suggestion for the composition of the governing board of the proposed Center for Defender Services should be applied to the composition of the Defender Services Committee. If there is an inkling of giving defenders some independence within the present judicial structure, judicial members should be eliminated from this committee of the Judicial Conference.

\section{IV}

\section{INDEPENDENCE AT THE LOCAL LEVEL}

In structuring authority over federal defenders, Congress adopted the essential principle of local control, but left it in the hands of the federal district judges. Now the district court exercises almost unlimited control in choosing whether to create a defender organization or utilize a panel of attorneys. The district court determines the selection and compensation of the CJA panel attorneys and authorizes and compensates investigators, experts, and others. ${ }^{34}$ This pervasive control, both in fact and appearance, undermines zealous defense advocacy.

If a federal public defender organization is created, the district court recommends candidates for the position of director, and the court of appeals appoints the federal public defender ("FPD") for a four-year term. 35 The power to appoint an FPD includes the power to fire one, and the court of appeals has done this more than once based upon the initiative of the district court. In some districts, FPDOs have been closed.

The court of appeals makes the formal selection of the FPD, but not without the powerful input from the district court bench. In most cases, the district court's recommendation is decisive in the selection of the candidate. In a few cases, a dissonant court of appeals has appointed an FPD not to the liking of

32. Committees of the Judicial Conference need not be composed solely of federal judges. Presently, for example, the Committee on Rules of Practice and Procedure and the Committee on International Judicial Relations have members who are not judges. Memorandum from the Administrative Office of the U.S. Courts (Jan. 3, 1995) (on file with author).

33. Some present and past federal defenders have urged that the Defender Services Committee include, as at least one-third of its representation, lawyers skilled and experienced in the delivery of defender services. Obviously, prosecutors should not be included. Presently, one or more federal defenders and an appointed counsel are permitted to meet with the all-judge Defender Services Committee, but without the right to vote. This tokenism belies even a semblance of real participation and reveals the greater need to provide a structural change to guarantee freedom from subservience to the judiciary.

34. A district court may use its power to cut CJA vouchers for attorneys and to authorize and cut them for investigators, experts, and other assistance to manifest its displeasure with "too much defense advocacy." An ethical judge may not like the position of being the administrator for the defense team.

35. 18 U.S.C. \& $3006 \mathrm{~A}(\mathrm{~g})(2)(\mathrm{A})(1988)$. 
the district court, but in such cases the FPD has taken a beating in the selection process. ${ }^{36}$ If the judges are able to so influence the selection process, the FPD appears to be the lackey of the district court or the court of appeal, whichever exercised the true power of appointment. ${ }^{37}$

Chief Judge Wallace of the Ninth Circuit explained the obvious dilemma that arises when judges are involved in the appointment of the FPD:

The judges who must evaluate whether to appoint a defender seeking a subsequent term are the same judges who evaluate the defender and the defender's staff's appellate arguments and performances.

It is the strong consensus of those circuit judges who have been serving on the Ninth Circuit committee which administers these appointment procedures that it is inappropriate for a Court of Appeals to exercise this responsibility. These judges urge [the Prado] Committee to propose an alternative institution to appoint and to remove federal public defenders. This sentiment coincides with the recommendation of the Federal Courts Study Committee which objected to the role of judges in the appointment and removal processes of federal public defenders. ${ }^{38}$

Although these comments were made about the selection of FPDs in the Ninth Circuit, other courts of appeal have been less independent in the exercise of the power to appoint and often defer to the recommendation of the district court. ${ }^{39}$ If an FPD is subject to such judicial control, his ability both in fact and in appearance to represent zealously the criminally accused is compromised.

Under existing law, the alternative to the FPDO is the Community Defender Organization (the "CDO"). ${ }^{40}$ CDOs are less numerous than FPDOs, but are present in several major federal criminal jurisdictions within the United States: New York City, Chicago, Detroit, ${ }^{41}$ San Diego, and Atlanta. The CDO can be a separate organization or a part of a preexisting defender services organization. ${ }^{42}$ The $\mathrm{CDO}$ is a local nonprofit corporation governed by a board of

36. The Ninth Circuit several times has appointed FPDs who, because they were not welcomed by the district courts, became "aliens" in the districts. Since the district courts originally had the practical power of appointment of the FPD, they now do not readily submit to newly asserted direction of the courts of appeals.

37. When the district judges select a magistrate judge, there is a more formal procedure to ensure merit selection than the statutory system for the selection of an FPD director. See 28 U.S.C. $\$ 631$ (1988 \& Supp. V 1994). It may be appropriate for judges to select judges, but it is not appropriate for judges to select advocates who regularly appear before them to challenge the government.

38. COMMITTEE REPORT, supra note 3, at 2287.

39. In the past, the Ninth Circuit appointed all federal public defenders on the recommendation of the district court. However, that circuit has recently begun appointing FPDs not favored by the district court. Other courts of appeals usually give great deference to the district court, and even if several candidates are submitted by the district court, that court's preference among the candidates will be given great weight.

40. 18 U.S.C. $\$ 3006 \mathrm{~A}(\mathrm{~g})(2)(1988)$.

41. In September 1994, Paul Borman, the director of the Legal Aid and Defender Association of Detroit, a CDO, became the first federal defender appointed to the federal bench. His appointment constitutes a major breakthrough toward the ultimate goal of treating the federal defender in a similar fashion to his professional counterpart, the U.S. Attorney. The U.S. Attorney position is often a stepping-stone to the federal bench.

42. The CDOs in New York City are branches of the long-established Legal Aid Society, which also provides defender services in the state court. 
directors, which selects the director of the defender office. The CDO receives an annual grant much as an FPD receives an authorized budget. The bar is actively involved in these organizations, which ensures their professional independence and that they are representative of the community. The value of a board of directors as a link to the community, not just to the bar, and as a buffer from both the prosecutor and bench, cannot be overestimated.

The Prado Committee suggested that the FPDO have a local advisory board that would operate as this link and buffer. ${ }^{43}$ The local board could also serve as an ongoing performance evaluator of the defender when it comes time for reappointment. The local board would alleviate the concerns about judicial control of the defender function. For the FPD, who has operated without such a board, the board may be considered a nuisance. For the director of the CDO, the board is an excellent in-house sounding board for free advice and assistance not now available to the FPD. Despite these advantages, the Judicial Conference rejected the Prado Committee's suggestion.

\section{$\mathrm{V}$ \\ OTHER NEEDED REFORMS}

\section{A. Term Limits and Turnover for Federal Defenders}

The courts of appeals are now grappling with the difficulties in selecting an FPD after an incumbent has served a term of four years. Should the selection process be open to all applicants, or should the incumbent be given preference? The appointment process for an FPD, like that for any politician, is critical, and those who exercise the power of appointment have a powerful influence on that office holder. Presently, the district courts still exercise strong if not controlling influence on the replacement of the FPD. A truly impartial judge who must rule on the advocacy of the FPD on behalf of unpopular clients should not want control over the livelihood of the advocate. Such control diminishes the stature of the judge and of the FPD. ${ }^{44}$

A recommendation made to the Prado Committee, but not adopted, was to impose a term limit of ten years on the director of an FPD or CDO. The principles of democracy and history teach us the need to limit the tenure of public officials. After a four-term presidency, a constitutional amendment was passed to limit that office to two terms. ${ }^{45}$ After the inability of several presidents to remove the entrenched director of the FBI, Congress limited the term of that office to ten years. ${ }^{46}$ The ten-year term balances the need for experience and a guarantee of some tenure against the danger of institutional-

43. COMMTTEE REPORT, supra note 3, at 2301-02.

44. Recently, a 12-year FPD applied for a fourth term, but was rejected and will now leave that office.

45. U.S. CONST. amend. XXII.

46. Crime Control Act of 1976, Pub. L. No. 94-503, tit. II, § 203, 90 Stat. 2407, 2427. 
ization. ${ }^{47}$ The director of an FPD or CDO with a ten-year term can plan for his or her successor. Orderly change in leadership is healthy. ${ }^{48}$ Perhaps the FPD might choose to remain with the office if financial security were a consideration, but an effective advocate should be able to survive in legal practice outside the embryonic support of mother government.

The concept of turnover should also be applied to the staff of the office. Like a law firm, the defender office should have some suitable pruning system that allows both for the turnover of associates and the recruitment of partners to create the stable core element of experience essential for a federal defender office. The majority of federal defender offices recruit only from the ranks of experienced lawyers, but every defender office should have entry-level positions for recent law graduates. The influx of young lawyers adds an energetic and questioning approach that complements the work of the experienced staff. To use recent law graduates, the defender office must have a strong internal training program and a commitment from the graduates to make sacrifices to earn the necessary experience. ${ }^{49}$

\section{B. Continuity of Representation on Appeal}

The CJA expressly requires that trial counsel continue on appeal. ${ }^{50}$ However, because trials provide experience in addition to some compensation, many attorneys prefer them to the dry review of appeals. There are those who would accept trial appointments, but are not willing to continue on appeal. The statutory presumption in favor of continuity provides better and more efficient representation. A good trial lawyer will be aware of the legal requirements for preserving a good appeal and will be able to create an effective record for the appellate court. $^{51}$ Those attorneys who believe their role is limited to the trial

47. The 10-year limitation should apply equally to both FPDs and CDO directors. While the FPD has a four-year term, 18 U.S.C. $\$ 3006 \mathrm{~A}(\mathrm{~g})(2)(\mathrm{A})(1988)$, the director of a CDO serves at the will of the board. COMMTTEE REPORT, supra note 3, at 2274. The 10-year limitation would stimulate the preparation of a capable successor from within the office as well as give adequate notice for a search from without.

48. The proposed 10-year limit should apply only prospectively from the date of its imposition, because several FPDs have earned stature in their legal community that has counterbalanced the influence of the court. The 10-year limit should be implemented to achieve, not defeat, the independence of an incumbent FPD or director of a CDO.

49. The San Diego and Spokane CDOs require all attorneys to agree in writing to a minimum 60hour work week to address the needs of the clientele and to participate in weekly evening and Saturday training sessions. During their minimum two-year service, young associates gain from the experience and training and at the same time returm the benefits of this training to the clients.

50. "A person for whom counsel is appointed shall be represented at every stage of the proceedings from his initial appearance before the United States Magistrate or the court through appeal, including ancillary matters appropriate to the proceedings." 18 U.S.C. $\$ 3006$ A(c) (1988). The court also has the right to substitute appointed counsel at any stage.

51. In former times, the trial lawyer focused principally on facts presented to a jury, and the appellate lawyer was the brief writer, knowledgeable of then-limited federal criminal law and procedure. Today, the complexity of federal law, which permeates every stage of the trial and sentencing, requires that every defense attorney be responsible for asserting and preserving every viable legal issue for later review. The trial defense lawyer must have a comprehensive knowledge of this growing specialty to preserve legal issues for review properly. 
might not be so diligent in preserving not only the legal error but the context that makes it prejudicial. Additionally, if lawyers who try cases are not the ones writing the appeals, then another lawyer must become familiar with the client and the case. Legal issues are not evaluated in the abstract, but in how they impact the presentation of the defense, and this needs to be articulated for the appellate court. ${ }^{52}$ An appellate panel of attorneys without substantial trial experience cheats both the client and the court. Therefore, attorneys who will not follow through on the appeal, an obligation owed primarily to the client, should not be on the trial panel. An exception may exist where there is a volume of cases in a defender office that might justify appellate specialization, but this justification would require close coordination between the trial and appellate sections to avoid duplication of effort. ${ }^{53}$

If a question about the competency of the trial attorney is raised, of course, other counsel should be appointed. However, in light of the paucity of cases that get reversed for ineffective assistance of counsel, this should not be an open-ended excuse for trial counsel to be relieved of taking the appeal. Unless the trial attorney's performance is legitimately questioned, the duplication of appellate counsel when CJA funds are limited cannot be justified.

\section{Training for Defense Attorneys}

In 1986, the CJA was specifically amended to authorize training for attorneys appointed under the Act. ${ }^{54}$ Prior to that time, each office conducted its own training, but in December 1983, a one-week training program for new attorney staff of federal defender offices was initiated at the Federal Law Enforcement Training Center at Glynco, Georgia. This orientation program, which is generally still available to new attorneys, has now been supplemented with a two-week practical skills course at the National College of Criminal Defense at Mercer School of Law in Macon, Georgia, when space has been made available.

This limited training for new attorneys is grossly inadequate for those who are required to become immediate specialists in federal criminal law, with its complex and draconian sentencing guideline scheme. Even an experienced state criminal law practitioner needs orientation as to the intricacies of federal criminal law and practice. The Army offers a ten-week basic skills course to its new judge advocate officers (military lawyers) at the U.S. Army Judge Advocate

52. Sentencing issues are now as important as pretrial or trial issues. If the trial lawyer has not properly developed the sentencing issue or has failed to object, the issue will not be reviewed by the appellate court. United States v. Hernandez-Rodriguez, 975 F.2d 622, 628 (9th Cir. 1992) (no review except for plain error); United States v. Livingston, 936 F.2d 333, 335 (7th Cir. 1991).

53. In the widespread military justice system, the military attorneys who handle the appeals are not necessarily the same as those who defend the accused at trial. E.g., U.S.A.F Instruction 51-201, ch. 11 (1994). However, special circumstances justify this bifurcation.

54. The Criminal Justice Act Revision of 1986, Pub. L. No. 99-651, § 102(a)(6), 100 Stat. 3642,3645 (codified as amended at 18 U.S.C. $\$ 3006 \mathrm{~A}(\mathrm{i})$ (1988)), inserted a provision for funding continuing education and training of persons providing representational services under the CJA. 
General's School in Charlottesville, Virginia. ${ }^{55}$ The Army wisely invests in its new lawyers, who will be using a criminal justice system that is in many ways copied from the federal system. The same skills course should be provided for all those who serve full-time in an FPDO or CDO.

Each defender office should have its own in-house initial and continuing training program. Entry-level, advanced, and specialized programs should be conducted on a national level. Attorneys, as well as investigators and other staff, should be able to devote their full time to this intensive training. Each defender office, no matter how small, must have the capability of conducting training for the panel attorneys. In the efficient use of federal funding, the federal defenders could probably arrange to use the excellent Army training facility and gain much from the military's experience in preparing lawyers for a new specialty.

In 1993, the Administrative Office initiated a national training program for appointed panel attorneys. It was named "Only the Strong Survive," because those who practice federal criminal defense are aware of the beating defense counsel take on the not-so-level playing fields of the federal courts. These regional training programs were again conducted last year, but because two attorneys were removed from future training programs for making improper remarks $^{56}$ found offensive to the judiciary, the federal defender directing the programs resigned, and almost all of the National Association of Criminal Defense instructors withdrew. The reasons for the removal of the two attorneys are not at issue, but the control by the judiciary is.

\section{Limited Right of Client to Select Counsel}

A defendant charged with child molestation in state court complained that his public defender could not present a defense and referred to the attorney as a "dump truck." At a jury trial—over the protestation of the defendant that he was receiving ineffective assistance of counsel-the defense lawyer did not voir dire the jury, made no objection during the prosecution's presentation of the case, made no opening statement, cross-examined no prosecution witness, presented no evidence on behalf of the defendant, and waived closing argument to the jury. The California Court of Appeal, finding no prejudice, affirmed the conviction and characterized the actions of trial defense counsel as a "stealth defense." $" 57$

55. The Air Force has a similar program at its Judge Advocate General's School in Maxwell, Alabama.

56. One used a four-letter word, and the author used the phrase "Sieg Heil," German for "hail victory." Some federal defenders use the term to satirize what they perceive as a judicial mind-set that the government must always win.

57. People v. Huffman, 139 Cal. Rptr. 264 (Cal. Ct. App. 1977). The appellate court, demonstrating its protective instincts for the institutional defender, commented that retained counsel were often not equal to the public defender. Id. at $267 \mathrm{n} .2$. 
Reviewing courts are extremely reluctant to reverse criminal convictions because of the alleged substandard performance of defense counsel. ${ }^{58}$ The result is that a defendant may be forced to trial with an attorney whom he or she believes is a "dump truck," but has no recourse on appeal. This hardly breeds confidence in the judicial system.

One of the recommendations of the Prado Committee that was adopted by the Judicial Conference and forwarded to Congress called for the creation of volunteer pilot programs in the districts to give certain CJA-eligible defendants a limited choice of counsel. ${ }^{59}$ This limited choice of counsel imparts to the defendants a sense of responsibility for their own fate. Also, the availability of a choice stimulates a desire to be wanted on the part of the attorneys in the pool of potential counsel. This recommendation will help provide feedback from the clients, which must be built into the system.

In the San Diego CDO, any client who was not satisfied with the services of a particular staff attorney was interviewed by the head of the office. If the client had serious problems in relating to the initially designated attorney, he or she was offered the choice of any available attorney in the office. When afforded the power to choose, the client often would continue with the same attorney. If the client was critical of the defender office as a whole, then the CDO recommended the appointment of a panel attorney, which was usually granted by the court. The client did not get to select a particular attorney, but had the ability to avoid an attorney who was perceived as inexperienced or uninterested. This procedure provided important feedback on the performance of the staff attorneys. Likewise, a client represented by a panel attorney could be given a choice of another panel attorney or a staff attorney of the FPDO or $\mathrm{CDO}$, if one existed in the district. ${ }^{60}$

The right to choose counsel emphasizes that the attorney works for the client and not for the "system": not for the court that makes the appointment and reviews the vouchers, and not for the government that pays for these services.

\section{VI}

\section{CONCLUSION}

The recent federal crime control legislation, the product of the biennial congressional effort to capitalize on the crime issue, expands federal criminal jurisdiction, greatly increases the number of offenses punishable by death or

58. See United States v. Cronic, 466 U.S. 648 (1984) (holding that, absent clearly prejudicial circumstances such as those found in Powell v. Alabama, 287 U.S. 45 (1932), even if inexperienced attorney performance is deficient, specific prejudice must be established before relief is granted). Cronic and other cases have established a form of judicial review that seldom finds prejudice; attorney performance is therefore rarely reviewed.

59. REPORT OF THE JUDICIAL CONFERENCE OF THE UNITED STATES ON THE FEDERAL DEFENDER PROGRAM 34 (1993).

60. The client could be given a list of five panel attorneys. The opportunity to select other counsel should occur early in the process and must take into consideration the problem of conflict of interest. 
long-term confinement (that is, "three strikes"), and geometrically increases the litigation of criminal cases. Such laws create the concomitant need for more qualified counsel for the accused. Those who are to be processed by the increasingly harsh federal system now more than ever need truly independent and zealous advocacy to obtain justice from an apparatus blinded by the perceived need for punishment. Adoption of the recommendation of the Prado Committee to restructure defender services would ensure their independence. The Judicial Conference's rejection and subversion of this minimal recommendation elevates the subservient partnership of the federal defender and the judicial bureaucracy over the essential loyalty owed to the client. 